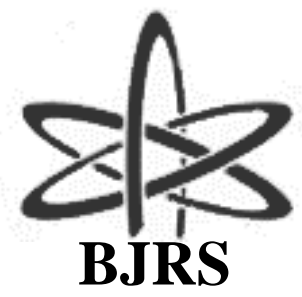

BRAZILIAN JOURNAL

$\mathrm{OF}$

RADIATION SCIENCES

09-01A (2021) 01-18

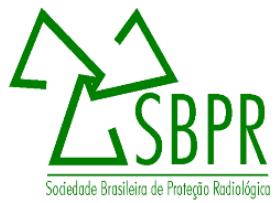

\title{
Development and application of an approach for safety assessment of radioactive waste storage facilities for accidental scenarios
}

\author{
Cota $^{\mathrm{a}}$ S.D.S., Passos ${ }^{\mathrm{a}}$ R.G., Vasconcelos ${ }^{\mathrm{a}}$ V. \\ ${ }^{a}$ Centro de Desenvolvimento da Tecnologia Nuclear-CDTN/CNEN, Av. Presidente Antônio Carlos, 6.627 \\ 31270-901, Belo Horizonte, MG, Brazil \\ sdsc@cdtn.com
}

\begin{abstract}
Worldwide there is a huge amount of radioactive waste, including disused sources, decommissioning waste, and naturally occurring radioactive material (NORM) waiting for final disposal, the so-called storage facilities. Results of safety assessment of such facilities are usually required in decision-making during design, modification, safety improvements, periodic safety reviews, and licensing activities. Quantitative safety assessment methodologies used in many areas of nuclear industry involves the evaluation of risk through the definition of scenarios, likelihoods, and consequences, for normal operation and accidents. There are many techniques that can be used in each one of these steps. For screening the accident scenarios, qualitative techniques such as failure modes and effect analysis (FMEA) are available. For a quantitative assessment of occurrence probabilities of undesired events, logical and graphical tools such as fault tree analysis (FTA) are employed. Consequence assessments involve the dose assessment in the workers and the impact of the released materials in the environment and of public exposure to radiation. This work analyzes the application of these traditional safety assessment approaches to storage facilities and how they can be applied to complement specific methodologies used in this area, such as the Safety Assessment Driving Radioactive Waste Management Solutions (SADRWMS), implemented in Safety Assessment Framework (SAFRAN) software tool, made available by International Atomic Energy Agency (IAEA).
\end{abstract}

Keywords: radioactive waste, safety assessment, accidents, SAFRAN, occurrence probability. 


\section{INTRODUCTION}

The 2014 regulatory position NN 8.02 [1], from the Brazilian Nuclear Energy Commission (CNEN) establishes the general criteria and basic safety conditions required for licensing of initial, intermediate and final storage facilities for low and intermediate activity level radioactive wastes. This regulation applies mainly for Class 2 wastes, comprising low and intermediate activity level wastes containing beta/gamma emitters with half-life below 30 years and a limited concentration of long half-life alpha emitters. Only packaged wastes containing naturally occurring radioactive materials (NORM) originated from petroleum and mining activities (Classes 2.2 and 2.3, respectively) are included in the scope of this regulation.

For applying for the operation license of initial and intermediate storage facilities, operators must elaborate a Final Safety Analysis Report (RFAS, in Portuguese) according to the specific requirements stated at the Annex II (following the Article 13, Section III) of the CNEN NN 8.02. In Item 6 of the Annex II, the regulation requires the development of a safety assessment of the facility, in order to demonstrate the radiological risks that operational personal, public and environment will be exposed as result of the facility operation under normal situation and accidents. For the analysis of accidents, the regulation requires the identification of the postulated initiating events (PIEs), the sequence of accidental events, the devices, mechanisms and actions to prevent accidents or mitigate their consequences, the estimative of the potential doses for workers and critical group (public individual) and an analysis of the risk in terms of the probability of occurrence and the estimated doses.

In 2015, the International Atomic Energy Agency (IAEA) issued a Technical Document (TECDOC) describing the conclusions of the 2004-2015 International Project on Safety Assessment Driving Radioactive Waste Management Solutions (SADRWMS). This project aimed to develop approaches and mechanisms for the application of safety assessment methodologies for the predisposal management of radioactive wastes [2].

The methodologies developed on the project were implemented in a user-oriented software tool: Safety Assessment Framework - SAFRAN [2]. This tool encloses all aspects of the predisposal waste management activities, including interim storage, and performs quantitative estimations for 
normal operation and accidents. Three main information groups are required: system description (including room/areas, processes, activities, waste stream and components, and inventory); Regulatory framework (with criteria for normal operation and accidental situation); Safety assessment (estimative of doses for normal operation and accidental situations for a given purpose and scope).

In SAFRAN, scenarios are assumed as sets of conditions or events that can lead to human or environmental exposure. Scenarios led to the definition and quantification of different radiological impacts (consequences) and the probability of occurrence, as well as the effect of safety elements. Despite the fact that SAFRAN requires the input of the probabilities associated to each scenario, either qualitative or quantitatively, no ways of estimating these values are provided by the methodology.

In this context, this paper provides a discussion of using different quantitative safety assessment techniques traditionally used in many areas of nuclear industry for the definition of scenarios, likelihoods, and consequences, for normal operation and accidents, and for the estimative of occurrence probabilities of undesired events. Despite the fact that these methodologies are focused in safety assessment for interim storage for radioactive wastes, they may be also applicable for other aspects of radioactive waste management.

\section{PROPOSED SAFETY ASSESSMENT METHODOLOGY}

\subsection{SADRWMS methodology and SAFRAN tool description}

Figure 1 shows a diagram for the methodology proposed for risk evaluation of accidental scenarios in the management of radioactive waste storage. The first three modules are calculated using SAFRAN software, according to the SADRWMS methodology.

The first module (assessment definition) involves the definition of the assessment context (purpose, philosophy, endpoints, timeframes and regulatory framework) and the description of the facility, activities and the wastes, including engineering design, safety measures, operational experience, isotopic inventory, waste components and streams, etc. 
Figure 1: Diagram of the methodology for risk evaluation of accidental scenarios (based on SADRWMS methodology).

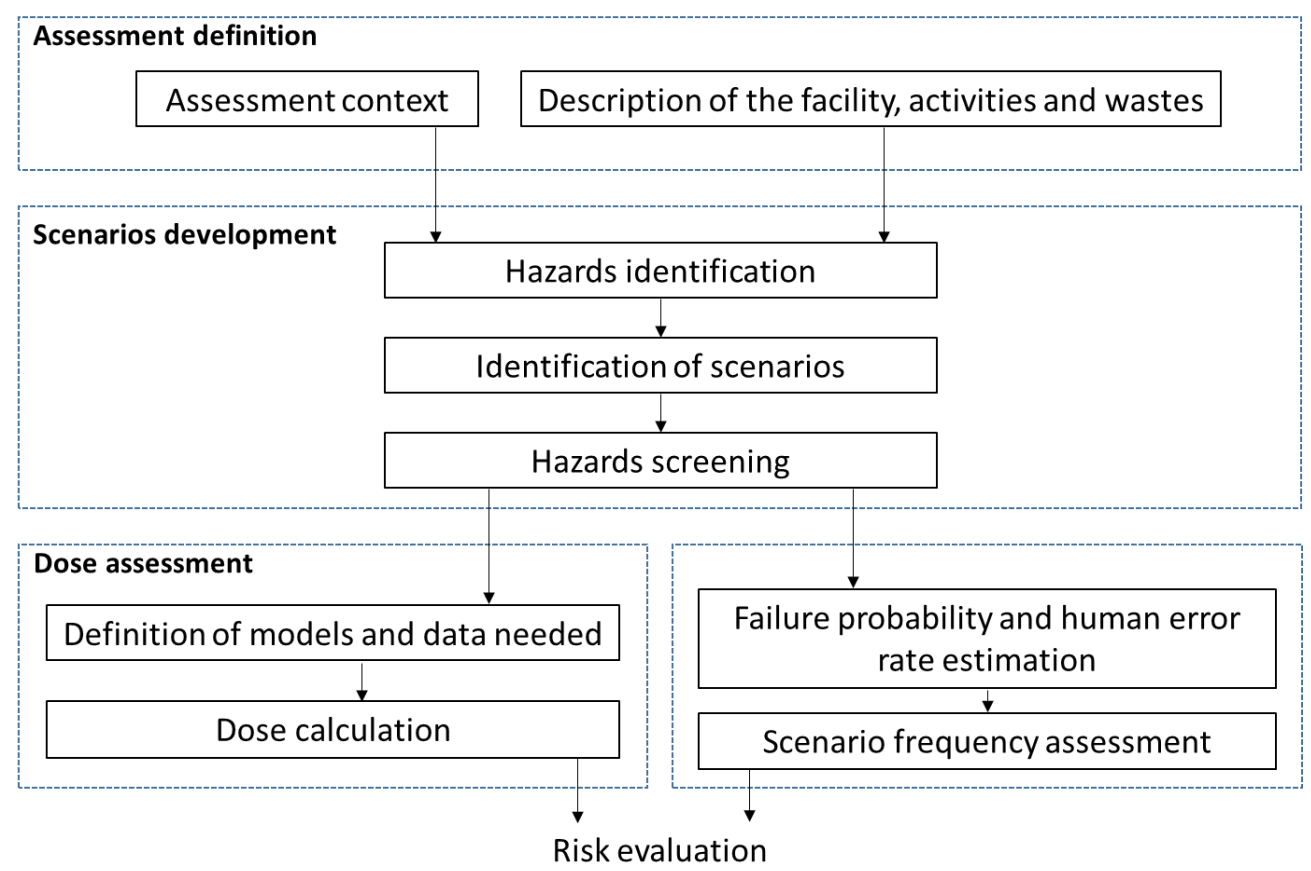

For the scenarios development module, lists of PIEs and expert judgments can be used to identify the hazards and identify related scenarios and impacts. A hazard screening is used to select which scenarios should be detailed for the risk evaluation, involving the quantification of the impacts corresponding to each scenario and comparing the results with screening values estimated for a generic, conservative, situation.

For the selected scenarios, the next step (dose assessment module) is the definition of models and data necessary for the dose estimative for the specific, more realistic exposure situation and endpoints. For these estimates, SAFRAN provides different models, gathered in a tool called SAFCAL, that can be applied to several specific geometries and situations. In this tool, models are available for dose estimative for point, cube, disc, and axial and radial drum geometries, with or without shielding (concrete, lead, and water). 


\subsection{Methodologies for Probability Assessment}

For implementing the complete risk evaluation for accidental scenarios, SADRWMS methodology requires also the estimative of the frequency of occurrence. This work suggests the use of different methods for the probability assessment such as fault tree analysis (FTA) and Poisson model, as will be discussed below. With the scenario-specific dose estimative and the corresponding probability, the risk evaluation can be accomplished by comparing with the dose criteria established by regulation framework.

For an initial screening of Postulated Initiating Events (PIEs), qualitative techniques such as failure modes and effect analysis (FMEA) are available. For a quantitative assessment of occurrence probabilities of undesired events, methods such as fault tree analysis (FTA), human reliability analysis (HRA), Poisson model, probabilistic seismic hazard analysis (PSHA), structural reliability analysis (SRA), and methodologies suggested by the United States Nuclear Regulatory Commission (USNRC) are employed. Tables 3 and 4 show, respectively, external natural events and internal events adopted by SAFRAN as PIEs, and the methods suggested in this work for assessing annual probability of occurrence of PIEs. These methods are briefly described below.

\section{(a) Failure modes and effect analysis (FMEA)}

FMEA is a qualitative (or semi-quantitative) analysis technique which can be used to select the most important failures in order to prioritize accident scenarios for further quantitative assessment. FMEA is a method designed to identify and understand potential failure modes and their causes, and the effects of failure on a product or process [3]. Table 1 is an example of a Generic FMEA Worksheet. Meanings of the columns of Table 1 are given in Table 2.

Table 1: Example of a generic FMEA worksheet.

\begin{tabular}{cccccc|c|c|c|c}
\hline $\begin{array}{c}\text { Item / } \\
\text { Function }\end{array}$ & $\begin{array}{c}\text { Potential } \\
\text { Failure } \\
\text { Mode(s) }\end{array}$ & $\begin{array}{c}\text { Potential } \\
\text { Effect(s) } \\
\text { of Failure }\end{array}$ & S & $\begin{array}{c}\text { Potential Cause(s)/ } \\
\text { Mechanism(s) of } \\
\text { Failure }\end{array}$ & O & $\begin{array}{c}\text { Current } \\
\text { Design } \\
\text { Controls }\end{array}$ & D & RPN & $\begin{array}{c}\text { Recommended } \\
\text { Action(s) }\end{array}$ \\
\hline I & II & III & IV & V & VI & VII & VIII & IX & X \\
\hline
\end{tabular}


Table 2: Meanings of columns of Table 1.

\begin{tabular}{|c|c|}
\hline Column & Potential Failure Mode(s) \\
\hline I & $\begin{array}{l}\text { A "function" is what the item or process is intended to do, usually to meet a given } \\
\text { standard of performance or requirement. }\end{array}$ \\
\hline II & $\begin{array}{l}\text { A "failure mode" is the manner in which an item potentially fails to meet the intended } \\
\text { function and associated requirements. }\end{array}$ \\
\hline III & $\begin{array}{l}\text { An "effect" is the potential consequence of the failure on the system or end user, and } \\
\text { there may be more than one effect for each failure mode. }\end{array}$ \\
\hline IV & $\begin{array}{l}\text { "Severity" (S) is a ranking number associated with the most serious effect for a given } \\
\text { failure mode, based on the criteria from a severity scale (there are many different } \\
\text { severity scale types, depending on FMEA application). }\end{array}$ \\
\hline $\mathbf{V}$ & $\begin{array}{l}\text { A "cause" is the specific reason for the failure and "failure mechanisms" are the } \\
\text { physical, chemical, thermodynamic or other processes that result in failure. }\end{array}$ \\
\hline VI & $\begin{array}{l}\text { "Occurrence" }(\mathrm{O}) \text { is a ranking number associated with the likelihood that the failure } \\
\text { mode and its associated cause will be present in the item being analyzed. As severity } \\
\text { ranking, there are different occurrence scale types. }\end{array}$ \\
\hline VII & $\begin{array}{l}\text { "Current Controls" are the methods or actions in place to prevent or detect causes, in } \\
\text { order to reduce or eliminate risks. }\end{array}$ \\
\hline VIII & $\begin{array}{l}\text { "Detection" (D) is a ranking number that considers the likelihood of detection of the } \\
\text { failure mode/cause, according to defined criteria. As severity and occurrence ranking, } \\
\text { there are different detection scale types. }\end{array}$ \\
\hline IX & $\begin{array}{l}\text { "Risk Priority Number" (RPN) is a numerical ranking of the risk of each potential } \\
\text { failure mode/cause, made up of the arithmetic product of the three elements "S", "O" } \\
\text { and "D" (RPN = A x O x D). }\end{array}$ \\
\hline $\mathbf{X}$ & $\begin{array}{l}\text { "Recommended actions" are the tasks recommended as result of FMEA study, to reduce } \\
\text { or eliminate the risk associated with a potential cause of failure. }\end{array}$ \\
\hline
\end{tabular}

\section{(b) Fault tree analysis (FTA)}

FTA is a top-down logical model relating a top event (usually an undesired event, such as an initiating event a risk analysis) to its root causes (called intermediate and basic events) through logical "AND" and "OR" gates. Figure 1 shows examples of "OR" (a) and "AND” (b) gates of a fault tree relating the intermediate events (rectangles) to basic events (circles). Using Boolean algebra rules, as well as probability theory and statistics, quantitative assessment of top event probability can be carried out if the probabilities of the basic events are available [4]. 
Figure 1: Examples of "OR” (a) and “AND” (b) gates of a fault tree.

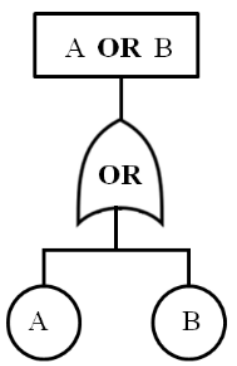

(a)

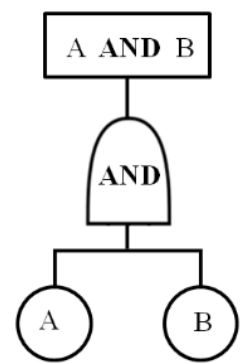

(b)

\section{(c) Event tree analysis (ETA)}

ETA is a binary tree used for modeling accident scenarios, which starts with the initiating event and proceeds through a series of successes or failures of engineered barriers, until an end-state is reached [5]. Fig. 2 illustrates an event tree for a generic initiating event and two engineered barriers. Considering $\lambda_{\text {ie }}$ as the occurrence frequency of an initiating event, and $p_{1}$ and $p_{2}$, as the probabilities of failure of engineered barriers 1 and 2, respectively, the frequency of occurrence, $F_{N}$, $F_{A}, F_{B}$ and $F_{C}$, for the possible end-states (no-consequence, and accident scenarios 1, 2 and 3) can be calculated as shown in Fig. 2. These estimates are only valid if the events involved in each sequence are independent. The frequency and probability estimates can be obtained through available statistics, FTA or engineering judgment.

\section{(d) Poisson model}

Poisson model is used when the occurrence of events is represented by discrete random variables (DRV), i.e., the sample space has a finite or countable number of sample points [6]. Assuming that the events occur at an average constant rate, $\lambda$, given a time interval $(0, t)$, the Poisson distribution gives the probability, $\mathrm{P}(\mathrm{k})$, of exactly $\mathrm{k}$ events occurring in $(0, t) . \mathrm{P}(\mathrm{k})$ and standard deviation, $\sigma$, are given by Equations (1) and (2), respectively.

$$
\mathrm{P}(\mathrm{k})=e^{-\lambda t} \frac{(\lambda t)^{k}}{k !}
$$




$$
\sigma^{2}=\lambda \mathrm{t}
$$

This distribution is used to describe the occurrence of initiating events. For example, if an equipment fails due to mechanical shocks that occur, on the average, once every 100 hours $(\lambda=$ $0.01 / \mathrm{h})$, what is the probability of exactly one failure $(\mathrm{k}=1)$ in 100 hours $(\mathrm{t}=100$ hours $)$ ? Using Equation (1), $\mathrm{P}(\mathrm{k}=1)=0.368$, as shown in Equation (3).

$$
\mathrm{P}(\mathrm{k}=1)=e^{-0.01 \times 100} \frac{(0,01 \times 100)^{1}}{1 !}=0.368
$$

Similarly, the probability of no failure, $\mathrm{P}(\mathrm{k}=0)$, is also 0.368 , and the probability of two failures, $\mathrm{P}(k=2)$, is 0.185 . Following this example, the probability of at most two failures, $\mathrm{P}(\mathrm{k}=0$ or $\mathrm{k}=1$ or $\mathrm{k}=2$ ) is 0.921 , as shown in Equation (4).

$$
\mathrm{P}(\mathrm{k}=0 \text { or } \mathrm{k}=1 \text { or } \mathrm{k}=2)=0.368+0.368+0.185=0.921
$$

\begin{tabular}{|c|c|c|c|c|}
\hline Initiating Event & $\begin{array}{c}\text { Engineered } \\
\text { Barrier } 1\end{array}$ & $\begin{array}{c}\text { Engineered } \\
\text { Barrier } 2\end{array}$ & End-State & \\
\hline & \multirow[b]{2}{*}{ Success } & Success & \multirow{2}{*}{ No Consequence $(\mathbf{N})$} & $F_{N}=\lambda_{\mathrm{ie}}\left(1-\mathbf{p}_{1}\right)\left(1-\mathbf{p}_{2}\right)$ \\
\hline & & $1-p_{2}$ & & \\
\hline & $1-p_{1}$ & Failure & \multirow{2}{*}{ Accident Scenario A } & \\
\hline & & $p_{2}$ & & e $\left(\begin{array}{lll} & 010\end{array}\right.$ \\
\hline \multirow[t]{4}{*}{$\lambda_{\mathrm{ie}}$} & \multirow[b]{2}{*}{ Failure } & Success & \multirow{2}{*}{ Accident Scenario B } & \multirow{2}{*}{$F_{B}=\lambda_{\mathrm{ie}} \cdot \mathrm{p}_{1}\left(1-\mathrm{p}_{2}\right)$} \\
\hline & & $1-p_{2}$ & & \\
\hline & \multirow[t]{2}{*}{$p_{1}$} & Failure & \multirow{2}{*}{ Accident Scenario C } & $\boldsymbol{F}_{c}=\lambda_{\mathrm{i},}, \mathrm{r}$ \\
\hline & & $p_{2}$ & & \\
\hline
\end{tabular}

Figure 2: Example of an event tree and two engineered barriers. 


\section{(e) Human reliability analysis (HRA)}

Human reliability is the probability of humans conducting specific tasks with satisfactory performance, such as equipment inspection, maintenance or operation, safety actions, plant diagnosis or other kinds of human actions that influence system performance [6]. Human error (HE) is contrary to human reliability and the human error probability, $\mathrm{P}(\mathrm{HE})$, is given by Eq. (5):

$$
P(H E)=\frac{\text { number of errors }}{\text { number of errors oportunities }}
$$

There are many methods for Human Reliability Analysis (HRA), such as THERP (Technique for Human Error Rate Prediction) or SPAR-H (Technique for Human Error Rate Prediction). THERP is based on a human reliability tree, similar to event trees. SPARH defines human error probabilities based on specialist opinions to define the so-called performance-shaping factor (PSF) values, which are different depending on action or diagnostic tasks. If a task is considered as action type, its nominal error probability is $1 \mathrm{E}-3$, and the resulting $\mathrm{P}(\mathrm{HE})$ is the product of PSFs multipliers and this nominal value. If the task is considered diagnostic type, its nominal error is $1 \mathrm{E}-$ $2[7]$.

\section{(f) Other methods recommended by USNRC}

There many other methods recommended by USNRC which can be used for probabilistic analysis of initiating events or engineered barrier failures, such as probabilistic seismic hazard analysis [8], determination of the probability of an explosion at a nearby facility or transport routes of hazardous material [9], determination of the probability of an aircraft crashing into the plant [10], or generation of missiles and flying debris due to the explosion of pressurized components or rotating equipment [11]. The choice of adequate method depends on available data and computer models. 


\subsection{Assessment of Probability of Occurrence for Different PIEs}

For each PIE associated to accidental situations in the operation of radioactive waste storage facilities, it is possible to point the most appropriate method for estimating the associated probability of occurrence. Tables 3 and 4 bring an association between the most suitable method and some of the listed PIEs adopted by SAFRAN for external natural and internal events, respectively. This association was built based on the characteristic of each event and method, as well as recommendations of the literature, as indicated in the tables.

\subsection{Acceptance criteria considering dose and frequency}

Figure 3 establishes the relation between frequency and consequence (F-C curve) according to NUREG 1860 [16]. This curve is based on the principle that event frequencies and doses are inversely related. This express the idea that high dose (or consequences) can be considered acceptable if the associated probability of occurrence is very low. The curve divides the graphics into two regions of risk acceptability (acceptable and unacceptable regions) according to dose and frequency levels. This curve is proposed for use as licensing basis for nuclear power plants but can, in principle, be applied to other radioactive or nuclear facilities, as dose/frequency ranges for public.

After the evaluation of the dose using the SAFRAN software and the associate probability of occurrence for a given accidental scenario possible to occur in the operation of radioactive waste storage facilities, it is possible to use the curve to verify if the scenario can be considered acceptable. This curve can also be used for deciding if a specific technical solution for mitigating high operational risks will produce the expected results. 
Table 3: Examples of external natural events adopted by SAFRAN as Postulated Initiating Events (PIEs) and the suggested method for probability estimative.

\begin{tabular}{|c|c|c|}
\hline External Natural Events & $\begin{array}{l}\text { Method for assessing annual } \\
\text { probability of occurrence }\end{array}$ & Reference \\
\hline Lightning & Poisson Model & $\begin{array}{l}\text { Stamatelatos } \\
(2002 b)[5]\end{array}$ \\
\hline Seismic events & $\begin{array}{c}\text { Probabilistic Seismic Hazard } \\
\text { Analysis }\end{array}$ & $\begin{array}{l}\text { USNRC } \\
(1997)[8]\end{array}$ \\
\hline Potential for natural fires, storms, etc. & Poisson Model & $\begin{array}{l}\text { Stamatelatos } \\
(2002 \mathrm{~b})[5]\end{array}$ \\
\hline Flooding & Poisson Model & $\begin{array}{l}\text { Stamatelatos } \\
(2002 b)[5]\end{array}$ \\
\hline Explosion & Fault Tree Analysis (FTA) & $\begin{array}{l}\text { Stamatelatos } \\
\text { (2002a) [4] }\end{array}$ \\
\hline Fire & Fault Tree Analysis (FTA) & $\begin{array}{l}\text { Stamatelatos } \\
(2002 \mathrm{a})[4]\end{array}$ \\
\hline Aircraft crash & $\begin{array}{c}\text { Model suggested by NUREG } \\
0800\end{array}$ & $\begin{array}{c}\text { USNRC } \\
(2010)[10]\end{array}$ \\
\hline Power supply and the potential loss of power & Poisson Model & $\begin{array}{l}\text { Stamatelatos } \\
(2002 b)[5]\end{array}$ \\
\hline
\end{tabular}

Table 4: Examples of internal events adopted by SAFRAN as Postulated Initiating Events (PIEs) and the suggested method for probability estimative.

\begin{tabular}{lcc}
\hline \multicolumn{1}{c}{ Internal Events } & $\begin{array}{c}\text { Method for assessing annual } \\
\text { probability of occurrence }\end{array}$ & Reference \\
\hline $\begin{array}{l}\text { The acceptance (inadvertent or otherwise) of } \\
\text { incoming waste, waste containers, process } \\
\text { chemicals, conditioning agents, etc., that do not } \\
\text { meet the specifications (acceptance criteria) } \\
\text { included in the design basis. }\end{array}$ & $\begin{array}{c}\text { Human Reliability Analysis } \\
\text { (HRA) }\end{array}$ & $\begin{array}{c}\text { USNRC (2006) } \\
{[12]}\end{array}$ \\
$\begin{array}{l}\text { Explosion due to the evolution of explosive gas } \\
\text { mixtures. }\end{array}$ & Fault Tree Analysis (FTA) & $\begin{array}{r}\text { Stamatelatos } \\
\text { (2002a) [4] }\end{array}$ \\
$\begin{array}{l}\text { Spontaneous combustion. } \\
\begin{array}{l}\text { Local hot spots generated by malfunctions of } \\
\text { structures, systems or components. }\end{array}\end{array}$ & Monte Carlo Simulation (MCS) & $\begin{array}{c}\text { Tolentino (2015) } \\
{[13]}\end{array}$ \\
$\begin{array}{l}\text { Sparks from machinery, equipment or electrical } \\
\text { circuits. }\end{array}$ & Fault Tree Analysis (FTA) & $\begin{array}{c}\text { Stamatelatos } \\
\text { (SRA) }\end{array}$ \\
$\begin{array}{l}\text { Sparks from human activities such as welding or } \\
\text { smoking. }\end{array}$ & Human Reliability Analysis \\
\end{tabular}


Table 4 (Cont.): Examples of internal events adopted by SAFRAN as Postulated Initiating Events (PIEs) and the suggested method for probability estimative.

\begin{tabular}{|c|c|c|}
\hline Internal Events & $\begin{array}{l}\text { Method for assessing annual } \\
\text { probability of occurrence }\end{array}$ & Reference \\
\hline \multirow{2}{*}{ Explosions. } & \multirow{2}{*}{ FTA } & TNT Equivalent \\
\hline & & USNRC (2013) [9] \\
\hline $\begin{array}{l}\text { The degradation of process materials (chemicals, } \\
\text { additives or binders) due to improper handling and } \\
\text { storage. }\end{array}$ & $\begin{array}{l}\text { Human Reliability Analysis } \\
\text { (HRA) }\end{array}$ & $\begin{array}{l}\text { USNRC (2006) } \\
\text { [12] }\end{array}$ \\
\hline $\begin{array}{l}\text { The failure to take account of the non-radiological } \\
\text { hazards presented by the waste (physical, chemical } \\
\text { or pathogenic). }\end{array}$ & $\begin{array}{l}\text { Human Reliability Analysis } \\
\text { (HRA) }\end{array}$ & $\begin{array}{c}\text { USNRC (2006) } \\
\quad[12]\end{array}$ \\
\hline $\begin{array}{l}\text { Dropping waste packages or other loads due to } \\
\text { mishandling or equipment failure, with } \\
\text { consequences to the dropped waste package and } \\
\text { possibly to other waste packages or to the } \\
\text { structures, systems and components of the facility. }\end{array}$ & $\begin{array}{l}\text { Human Reliability Analysis } \\
\text { (HRA) }\end{array}$ & $\begin{array}{c}\text { USNRC (2006) } \\
\quad[12]\end{array}$ \\
\hline $\begin{array}{l}\text { Collisions of vehicles or suspended loads with the } \\
\text { structures, systems and components of the facility } \\
\text { or with waste packages, waste containment vessels } \\
\text { and pipes. }\end{array}$ & $\begin{array}{l}\text { Human Reliability Analysis } \\
\text { (HRA) }\end{array}$ & $\begin{array}{l}\text { USNRC (2006) } \\
\quad[12]\end{array}$ \\
\hline Failures of structures, systems and components & $\begin{array}{l}\text { Structural Reliability Analysis } \\
\text { (SRA) }\end{array}$ & $\begin{array}{l}\text { Kwag \& Gupta } \\
\text { (2017) [14] }\end{array}$ \\
\hline $\begin{array}{l}\text { The malfunctioning of equipment that maintains } \\
\text { the ambient conditions in the facility, such as the } \\
\text { ventilation system or dewatering system. }\end{array}$ & Fault Tree Analysis (FTA) & $\begin{array}{l}\text { Stamatelatos } \\
\text { (2002a) [4] }\end{array}$ \\
\hline $\begin{array}{l}\text { The malfunctioning of key equipment for handling } \\
\text { waste, such as transfer cranes or conveyors. }\end{array}$ & Fault Tree Analysis (FTA) & $\begin{array}{l}\text { Stamatelatos } \\
\text { (2002a) [4] }\end{array}$ \\
\hline $\begin{array}{l}\text { The malfunctioning of structures, systems and } \\
\text { components that control releases to the } \\
\text { environment, such as filters or valves. }\end{array}$ & Fault Tree Analysis (FTA) & $\begin{array}{l}\text { Stamatelatos } \\
\text { (2002a) [4] }\end{array}$ \\
\hline $\begin{array}{l}\text { Incorrect operator action due to inaccurate or } \\
\text { incomplete information. }\end{array}$ & $\begin{array}{l}\text { Human Reliability Analysis } \\
\text { (HRA) }\end{array}$ & $\begin{array}{c}\text { USNRC (2006) } \\
\quad[12]\end{array}$ \\
\hline $\begin{array}{l}\text { Incorrect operator action in spite of having accurate } \\
\text { and complete information. }\end{array}$ & $\begin{array}{l}\text { Human Reliability Analysis } \\
\text { (HRA) }\end{array}$ & $\begin{array}{c}\text { USNRC (2006) } \\
\quad[12]\end{array}$ \\
\hline Sabotage by employees. & Fault Tree Analysis (FTA) & $\begin{array}{l}\text { Vasconcelos et al. } \\
\quad \text { (2011) [15] }\end{array}$ \\
\hline $\begin{array}{l}\text { Traffic accident when transporting waste on-site to } \\
\text { processing facility or from processing facility to } \\
\text { storage building }\end{array}$ & $\begin{array}{l}\text { Human Reliability Analysis } \\
\text { (HRA) }\end{array}$ & $\begin{array}{l}\text { USNRC (2006) } \\
\quad[12]\end{array}$ \\
\hline
\end{tabular}


Figure 3: Proposed frequency-dose curve for public according to NUREG 1860 criteria [16].

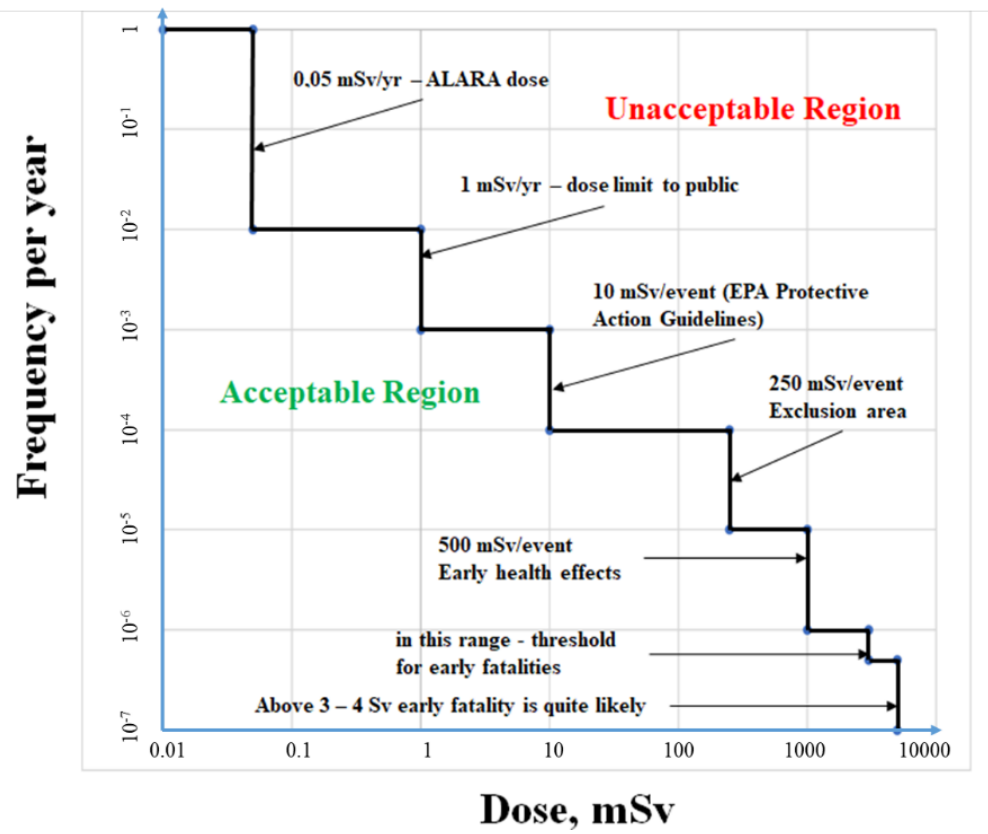

\section{CASE STUDY}

The methodology discussed on the previous item was applied for a case of accidental dropping of a package containing a single Cs-137 source with $2.6 \mathrm{E} 13 \mathrm{~Bq}$ of activity. This kind of accident can be a consequence of the handling of the package using a forklift by a no-trained operator inside a storage facility for disused sealed radioactive sources (DSRS). As a direct consequence of the dropping, the shielding loses its integrity due to the opening of the lid and the operator is directly exposed to radiation.

Despite the fact that the operator is using a personal dosimeter, no dose rate alarm is available in the facility, and the operator takes almost one minute to realize the opening of the package lid. Due to the same reason, the operator also gets closer one meter from the source to a distance of one meter in order to verify the best approach to retrieve the package.

The simulation done thru SAFRAN, conservatively using the model for a point source without shielding in SAFCAL, provides a dose rate of $2.19 \mathrm{~Sv} / \mathrm{h}$ at one meter from the source. For the exposure time of one minute, the operator would be exposed to a dose of $36.4 \mathrm{mSv}$. Assuming a 
public individual during one hour, at a distance of 20 meters from the DSRS and a concrete wall thickness of $20 \mathrm{~cm}$, the effective dose received would be $2.1 \mathrm{mSv}$.

According to the Table 5, the probability of a human error to cause an accident like this is calculated by the SPAR-H method, considering no-trained operator and no-optimal facility arrangements, is 6E-3 (assuming an action type task).

Using the Figure 3 and considering the handling of this type of DSRS once a year, it is possible to observe that this accident is in the unacceptable region, meaning that further actions must be taken to minimize the risks to public. Assuming a high-trained operator and an optimal arrangement of the facility, the frequency will be reduced to 5E-4 and the risk to public will be acceptable.

Moreover, a dosimeter with an alarm for high dose rates installed in the facility could give the operator the chance to a quickly evacuation of the area and that the retrieval operation could be done in a more controlled situation. In this scenario, the operator would be in the range of onemeter distance of the source for only 15 seconds, reducing the dose for $9.14 \mathrm{mSv}$, an effective dose lower than the annual limits for worker under normal operation. 
Table 5: Evaluation of PSFs for the task of handling the disused radioactive sources, applying the SPAR-H method (NUREG/CR-6883 [7]).

\begin{tabular}{|c|c|c|c|}
\hline PSFs & PSF Levels & Multiplier & Comments \\
\hline $\begin{array}{l}\text { Available } \\
\text { Time }\end{array}$ & $\begin{array}{l}\text { Inadequate time } \\
\text { Time available is } \approx \text { the } \\
\text { time required } \\
\text { Nominal time } \\
\text { Time available } \geq 5 \mathrm{x} \text { the } \\
\text { time required } \\
\text { Time available is } \geq 50 \\
\mathrm{x} \text { the time required } \\
\text { Insufficient Information }\end{array}$ & $\begin{array}{c}1 \\
0.1 \\
0.01 \\
1\end{array}$ & $\begin{array}{l}\text { Assuming that the dose rates inside facility of } \\
\text { DSRS are of the order of } \mu \mathrm{Sv} \text {, the dose limits to } \\
\text { worker are not exceeded even in continuous work } \\
\text { during a year. Then, nominal time is assumed. }\end{array}$ \\
\hline $\begin{array}{l}\text { Stress/ } \\
\text { Stressors }\end{array}$ & $\begin{array}{l}\text { Extreme } \\
\text { High } \\
\text { Nominal } \\
\text { Insufficient Information }\end{array}$ & $\begin{array}{l}5 \\
2 \\
1 \\
1\end{array}$ & $\begin{array}{l}\text { Even without time pressure to carry out the task, } \\
\text { a high stress to meet the ALARA criterion is } \\
\text { assumed. }\end{array}$ \\
\hline Complexity & $\begin{array}{l}\text { Highly complex } \\
\text { Moderately complex } \\
\text { Nominal } \\
\text { Insufficient Information }\end{array}$ & $\begin{array}{l}5 \\
2 \\
1 \\
1\end{array}$ & $\begin{array}{l}\text { The complexity of the forklift is not complex for } \\
\text { well-trained operators. }\end{array}$ \\
\hline $\begin{array}{l}\text { Experience/ } \\
\text { Training }\end{array}$ & $\begin{array}{l}\text { Low } \\
\text { Nominal } \\
\text { High } \\
\text { Insufficient Information }\end{array}$ & $\begin{array}{c}3 \\
1 \\
0.5 \\
1\end{array}$ & $\begin{array}{l}\text { For no-trained operators, the experience/training } \\
\text { the multiplier is considered } 3 \text {. For high-trained is } \\
\text { assumed } 0.5 \text {. }\end{array}$ \\
\hline Procedures & $\begin{array}{l}\text { Not available } \\
\text { Incomplete } \\
\text { Available, but poor } \\
\text { Nominal } \\
\text { Insufficient Information }\end{array}$ & $\begin{array}{c}50 \\
20 \\
5 \\
1 \\
1\end{array}$ & $\begin{array}{l}\text { This analysis was determined of a generic case } \\
\text { study and therefore nominal procedures is an } \\
\text { appropriate choice. }\end{array}$ \\
\hline $\begin{array}{l}\text { Ergonom- } \\
\text { ics/ } \\
\text { HMI }\end{array}$ & $\begin{array}{l}\text { Missing/Misleading } \\
\text { Poor } \\
\text { Nominal } \\
\text { Good } \\
\text { Insufficient Information }\end{array}$ & $\begin{array}{c}50 \\
10 \\
1 \\
0.5 \\
1\end{array}$ & $\begin{array}{l}\text { Considering an optimal arrangement of DSRS } \\
\text { storage facility, the ergonomics/HMI is } \\
\text { considered good. Otherwise, it is considered } \\
\text { nominal. }\end{array}$ \\
\hline $\begin{array}{l}\text { Fitness for } \\
\text { Duty }\end{array}$ & $\begin{array}{l}\text { Unfit } \\
\text { Degraded Fitness } \\
\text { Nominal } \\
\text { Insufficient Information }\end{array}$ & $\begin{array}{c}\mathrm{P}=1.0 \\
5 \\
1 \\
1\end{array}$ & $\begin{array}{l}\text { It is considered insufficient information on case } \\
\text { study about this PSF. }\end{array}$ \\
\hline $\begin{array}{l}\text { Work } \\
\text { Processes }\end{array}$ & $\begin{array}{l}\text { Poor } \\
\text { Nominal } \\
\text { Good } \\
\text { Insufficient Information }\end{array}$ & $\begin{array}{c}5 \\
1 \\
0.5 \\
1\end{array}$ & $\begin{array}{l}\text { It is also considered insufficient information on } \\
\text { case study about this PSF. }\end{array}$ \\
\hline
\end{tabular}




\section{CONCLUSION}

This paper proposes the joint use of the SADRWMS methodology and different quantitative safety assessment techniques traditionally used in many areas of nuclear industry for the definition of scenarios, likelihoods, and consequences methodology. This would provide dose and probabilities estimates for accidental scenarios applied for storage facilities for radioactive wastes, caused by external and internal initiating events and human related errors.

The use of the proposed methodology was applied to a case study of the mishandling of a package containing a high activity source causing exposure increase for the operator and the public. The results showed an unacceptable risk for this kind of accident and how additional administrative and technical arrangements were effective for reducing the risk to acceptable standards.

\section{REFERENCES}

[1] CNEN - Comissão Nacional de Energia Nuclear. Licenciamento de depósitos de rejeitos radioativos de baixo e médio níveis de radiação. Norma CNEN NN 8.02, Rio de Janeiro: CNEN, 2014.

[2] IAEA - International Atomic Energy Agency. Methodology for safety assessment applied to predisposal waste management. IAEA-TECDOC-1777, Vienna: IAEA, 2015.

[3] CARLSON, C.S. Understanding and applying the fundamentals of FMEAs. In: ANNUAL RELIABILITY AND MAINTAINABILITY SYMPOSIUM, 2014, Colorado Springs, CO, USA.

[4] STAMATELATOS, M. Fault tree handbook with aerospace applications, version 1.1. Office of Safety and Mission Assurance. Washington: NASA Headquarters, Washington DC, USA, 2002a.

[5] STAMATELATOS, M. Probabilistic risk assessment procedures guide for NASA managers and practitioners, version 1.1. Office of Safety and Mission Assurance. Washington: NASA Headquarters, Washington DC, USA, 2002b. 
[6] CALIXTO, E. Gas and oil reliability engineering. Modeling and analysis, Elsevier, Amsterdam: Netherlands, 2013.

[7] USNRC - U.S. Nuclear Regulatory Commission, The SPAR-H human reliability analysis method. NUREG/CR-6883, Washington: USNRC, 2005.

[8] USNRC - U.S. Nuclear Regulatory Commission, Recommendations for probabilistic seismic hazard analysis: guidance on uncertainty and use of experts, NUREG/CR-6372, Vols. 1 and 2, Washington: USNRC, 1997.

[9] USNRC - U.S. Nuclear Regulatory Commission, Evaluations of explosions postulated to occur at nearby facilities and on transportation routes near nuclear power plants, Regulatory Guide 1.91, Revision 2, Washington: USNRC, 2013.

[10]USNRC - U.S. Nuclear Regulatory Commission, Standard review plan for the review of safety analysis reports for nuclear power plants, LWR edition: design of structures, components, equipment, and systems. NUREG-0800, Chapter 3, Section 3.1.6 - Aircraft hazards, Washington: USNRC, 2010.

[11]USNRC - U.S. Nuclear Regulatory Commission, Standard review plan for the review of safety analysis reports for nuclear power plants, LWR edition: design of structures, components, equipment, and systems. NUREG-0800, Chapter 3, Section 3.5.1.3 - Turbine missiles, Washington: USNRC, 2007.

[12]USNRC - U.S. Nuclear Regulatory Commission, Evaluation of human reliability analysis methods against good practices, NUREG-1842, Washington: USNRC, 2006.

[13]TOLENTINO, I.B. Desenvolvimento de um simulador dinâmico de análise de consequência para indústrias de processos. Tese de Doutorado (Engenharia Química) Universidade Estadual de Campinas, Campinas: UNICAMP, 2015.

[14]KWAG, S.; GUPTA, A. Probabilistic risk assessment framework for structural systems under multiple hazards using Bayesian statistics. Nuclear Engineering and Design, v. 315, p. 20-34, 2017.

[15] VASCONCELOS, V.; ANDRADE, M.C.; JORDÃO, E. Use of risk assessment methods for security design and analysis of nuclear and radioactive facilities, In: INTERNATIONAL NUCLEAR ATLANTIC CONFERENCE, Belo Horizonte: Comissão Nacional de Energia Nuclear, 2011. 
[16]USNRC - U.S. Nuclear Regulatory Commission. Feasibility study for a risk-informed and performance-based regulatory structure for future plant licensing, NUREG-1860, Vol. 1. Washington: USNRC, 2007. 